\title{
PENERAPAN DAN TINGKAT EFEKTIVITAS TEKNIK BIOREMEDIASI UNTUK PERAIRAN PANTAI TERCEMAR MINYAK
}

\author{
Oleh \\ Yeti Darmayati $^{1)}$ dan Nur Fitriah Afianti ${ }^{1)}$
}

\begin{abstract}
APPLICATION AND EFFECTIVITY OF BIOREMEDIATION TECHNIQUE FOR OIL CONTAMINATED COASTAL WATERS. Oil pollution is often occurs in Indonesian marine waters and it has a significant impact on ecological and economical aspects. Physical and chemical approaches are common to be used to combat this pollution. Bioremediation is a promising method using biological approach that not been used yet for oil spill cleanup in Indonesian coastal environment. The success stories were reported mostly from sub-tropic region. This technique is potential to be used in Indonesia due to tropical climates and enormous microbial resources in Indonesian marine waters. However, intensive research and field tests are still needed to develop an appropriate method for application in Indonesia. One of bioremediation technique limitations is the suitability for each polluted sites. This paper will discuss about the application and the effectivity of bioremediation technique in other countries and research development of this technique for coastal environment in Indonesia.
\end{abstract}

\section{PENDAHULUAN}

Pencemaran minyak di perairan laut dan pesisir, khususnya di Indonesia sudah sering kali terjadi, baik dalam skala besar maupun kecil (Rusdi, 2008; Sudrajad, 2006; Gunanto \& Seo, 2010). Sumbernya beragam seperti buangan dari darat (sungai dan runoff perkotaan), buangan transportasi dan pencucian air ballast, rembesan alami, limbah industri, deposisi dari atmosfer, kilang minyak pantai, pengeboran minyak lepas pantai, kecelakaan transportasi laut dan kecelakaan pengeboran minyak lepas pantai (NRC, 2003).

Berbagai kerugian yang diakibatkan oleh pencemaran minyak ini baik berupa kerusakan ekosistem maupun penurunan kegiatan sosial ekonomi lautan sudah banyak diungkap oleh para ahli (Hose et al., 1996; Spies et al., 1996; White \& Baker, 1998; Maulidiyah, 2012). Hal ini disebabkan adanya kandungan senyawa yang bersifat toksik, karsinogenik bahkan mutagenik yaitu hidrokarbon poliaromatik (PAH). Disamping itu, karakteristik dan penampakan dari tumpahan minyak yang terdampar di pantai juga dapat menimbulkan dampak negatif seperti gangguan estetis dan kenyamanan perekonomian pariwisata.

Untuk menghindari dampak

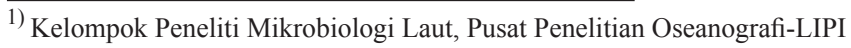


negatif dari pencemaran minyak, dikenal tiga pendekatan yaitu fisika, kimia dan biologis (Atlas, 1981). Cara fisika dan kimia sudah berkembang cukup lama dan lebih popular digunakan dalam menangani pencemaran minyak di Indonesia. Penggunaan teknik-teknik ini mungkin tepat untuk diterapkan di awal kejadian. Namun demikian, jarang sekali dapat membersihkan tumpahan minyak secara tuntas dan menyeluruh. Menurut Office of Technology Assessment (OTA, 1990), pendekatan mekanis hanya mampu memulihkan tidak lebih dari 10-15\% saja setelah kejadian. Penggunaan teknik biologi untuk menghilangkan polutan jauh lebih murah jika dibandingkan dengan pembersihan lingkungan dengan menggunakan teknik fisika dan kimia. Disamping itu, teknik ini juga lebih ramah lingkungan (Atlas, 1995). Untuk itu, teknik penanggulangan dengan menggunakan pendekatan biologis (bioremediasi) sangat dibutuhkan untuk memulihkan kembali lingkungan yang sudah tercemar.

Teknik bioremediasi dalam upaya pemulihan lingkungan yang tercemar minyak masih terus dikembangkan baik untuk di air, darat maupun pesisir. Khususnya untuk perairan pesisir, sudah banyak produk yang ditawarkan dan teknik yang diujicobakan di beberapa kejadian tumpahan minyak. Namun umumnya, teknik ini baru diterapkan di negara-negara maju yang beriklim subtropis. Disisi lain, teknik bioremediasi bersifat site specific (Prince \& Atlas, 2005). Keberhasilan teknik bioremediasi secara umum tergantung pada geografi, badan air, habitat, dan kekhasan lingkungan dari daerah yang tercemar.

Upaya pengembangan metode bioremediasi yang tepat dan murah merupakan tantangan bagi Indonesia. Hal ini disebabkan, karena lingkungan perairan Indonesia yang rentan terhadap gangguan pencemaran, salah satunya cemaran minyak. Di sisi lain, Indonesia memiliki potensi kekayaan mikroba laut yang dapat digunakan untuk mengatasi permasalahan tersebut. Disamping itu, kondisi iklim di Indonesia cukup mendukung untuk keberhasilan aplikasi teknologi tersebut. Namun sampai saat ini teknologi bioremediasi belum diterapkan, karena kurangnya informasi ilmiah. Tulisan ini disusun dalam upaya lebih mengenal sejauh mana pengembangan dan pemanfaatan teknologi bioremediasi di perairan pesisir, dan kemungkinan penerapannya di Indonesia. Materi yang akan dibahas meliputi pemanfaatan dan efektivitas teknik bioremediasi di luar negeri dan hasil penelitian yang sudah dilakukan di Indonesia.

\section{APLIKASI BIOREMEDIASI TUMPAHAN MINYAK DI LINGKUNGAN PESISIR MANCANEGARA}

Aplikasi bioremediasi untuk tumpahan minyak di lingkungan pesisir dan laut umumnya sudah dilakukan di negara-negara bagian utara yang beriklim dingin, seperti di Amerika, Eropa dan Asia Timur. Berbagai kecelakaan tumpahan minyak yang terjadi di kawasan 
tersebut telah memacu pengembangan dan penyempurnaan berbagai teknik penanganan pencemaran baik di laut ataupun pesisir, termasuk juga teknik bioremediasi. Beberapa hasil penelitian yang dilakukan setelah kecelakaan tumpahan minyak akan dibahas di bawah ini.

Kecelakaan tanker Amoco Cadiz di lepas pantai Perancis pada tahun 1978, telah mengakibatkan pencemaran yang luas di garis pantai. Penggunaan empat jenis produk yang berbeda telah diuji untuk mencari kemungkinan dalam meningkatkan biodegradasi minyak yang terperangkap dalam pasir. Produk tersebut berupa (1) senyawa pembersih yang mengandung nutrien untuk memulihkan tanah yang terkena minyak, (2) campuran bakteri, dispersan dan nutrien yang diliofilisasi, (3) pupuk kimia yang umum digunakan buat tanaman, dan (4) talk yang diberi perlakuan $0,1 \%$ surfaktan. Penelitian ini dilakukan dalam waktu yang terbatas sehingga studi yang dilakukan tidak tuntas dan hasil aplikasi sulit untuk disimpulkan. Perubahan kandungan minyak pada penelitian ini dapat teramati, akan tetapi tidak dapat disimpulkan apakah hal ini disebabkan oleh pemulihan akibat proses fisik atau proses biologi (Bocard dalam Swannell et al. 1996).

Proyek bioremediasi terbesar diujicoba di pantai berpasir dan berbatu Prince William Sound, setelah terjadinya kecelakaan Exxon Valdiz di Alaska pada tahun 1989. Uji coba inokulasi produkproduk mikroba untuk bioaugmentasi dan pemberian tiga jenis pupuk berbeda untuk biostimulasi telah dilakukan. Beberapa literatur menyimpulkan bahwa pemberian produk-produk bioaugmentasi telah gagal untuk meningkatkan biodegradasi minyak karena terbatasnya ketersediaan nutrien (Pritchard \& Costa dalam Zhu et al., 2001; Venosa et al. dalam Zhu et al., 2001). Adapun penggunaan pupuk anorganik larut air (pupuk taman 23:2 N:P), lepas lambat anorganik (Customblen) dan oleofilik (Inipol EP22) menunjukkan efektivitas yang beragam. Penggunaan hopane sebagai biomarker, dapat ditunjukkan bahwa pemberian pupuk dapat menurunkan minyak lima kali lebih cepat daripada kondisi alaminya. Selain itu, laju degradasi minyak sangat tergantung pada konsentrasi nitrogen dalam air pori pada sedimen di daerah pasang surut. Oleh karena itu, bioremediasi kawasan tercemar minyak memerlukan data akurat kandungan nutrien dalam air pori. Hasil monitoring nutrien di air pori akan memberikan panduan dalam penentuan pemberian jumlah nutrien yang tepat pada area yang tercemar (Bragg et al., 1994).

Beberapa uji lapangan diklaim berhasil menunjukkan keefektifan bioaugmentasi, seperti penggunaan Alpha BioSea $^{\mathrm{TM}}$ dalam penanganan tumpahan minyak Mega Borg di pesisir Texas (Mauro \& Wynne dalam Zhu et al., 2001) dan Terra-Zyme ${ }^{\mathrm{TM}}$ di tumpahan minyak Nakhodka, Jepang (Tsusumi et al., 2000). Formula kedua produk tersebut mengandung kultur bakteri dan nutrien (Hozumi et al., 2000). Namun kelemahan 
dari penelitian ini, antara lain observasi visual (Mega Borg) dan analisis gambar fotografi digital (Nakhodka) bukan diperoleh dari hasil monitoring verifikasi minyak yang hilang akibat bioremediasi.

Pada kecelakaan terbesar abad ini, di sumur minyak dan gas Deepwater Horizon, Teluk Meksiko, April 2010, diduga sebesar 4,9 juta barrel (780 juta liter) minyak jenis Macondo (minyak ringan dengan gravitasi API $=35,2$ ) lepas ke laut dari kedalaman reservoir $5000 \mathrm{~m}$. Berbeda dengan kejadian Exxon Valdez, kecelakaan di Deepwater Horizon ini terjadi di lepas pantai $(77 \mathrm{~km}$ dari daratan), sehingga kontaminasi di sedimen sangat terbatas hanya sampai $2,7 \mathrm{~km}$ dari wellhead. Pendekatan fisik dan kimia lebih menonjol dalam penanganan tumpahan minyak ini. Salah satunya adalah penggunaan dispersan COREXIT 9500. Hal ini dilakukan untuk mendispersi minyak yang keluar dari ujung pipa dan well head pada kedalaman laut $1500 \mathrm{~m}$. Ketika minyak terdispersi dengan sangat baik di kolom air dan populasi mikrobanya sudah teradaptasi dengan baik terhadap tumpahan minyak, seperti halnya di perairan Teluk Meksiko, biodegradasi minyak berjalan sangat cepat. Banyaknya rembesan minyak alami (400 ribu barel/ tahun) dan pengeboran lepas pantai di Teluk Meksiko adalah penyebab mikroba di perairan ini beradaptasi lebih baik terhadap minyak. Cepatnya pemulihan alami dari tumpahan minyak British Petroleum, di Deepwater Horizon ini dikarenakan beberapa hal seperti tipe minyak mentah, pengaliran minyak ke laut dalam, penyebaran yang cepat dan adaptasi mikroba (Atlas \& Hazen, 2011).

\section{HASIL PENELITIAN BIOREMEDIASI PERAIRAN PESISIR INDONESIA}

Banyak hasil studi yang menunjukkan bahwa teknik bioremediasi efektif, murah dan aman bagi lingkungan. Namun demikian, penerapan teknik bioremediasi untuk memulihkan lingkungan tercemar minyak di Indonesia belum sampai pada tahap operasional rutin, melainkan masih dalam tahap uji coba lapangan dan umumnya terbatas hanya di darat. Beberapa penelitian dalam upaya pengembangan teknik bioremediasi di darat sudah dilakukan (Aditiawati et al., 2001; Sugoro \& Aditiawati, 2003; Yoswaty, 2002; Suardana, 2002). Disamping itu, aplikasinya juga sudah diuji-cobakan di beberapa lahan tambang minyak seperti milik PT Exxon, PT Total Indonesia dan beberapa perusahaan besar lainnya. IPB dan ITB juga sudah melakukan penelitian untuk bioremediasi di darat secara intensif bahkan telah mampu memproduksi agen bioremediasi yang teruji (Noorsalam \& Santosa: komunikasi pribadi).

Pemanfaatan teknik bioremediasi di laut dan kawasan pesisir sangat jarang dilakukan. Kalaupun ada, masih dalam tahap penelitian baik dalam skala laboratorium, semi lapangan (mesokosm), ataupun lapangan skala kecil. Hal ini diakibatkan kurangnya pemahaman akibat sangat minimnya 
studi bioremediasi di ekosistem tersebut, serta kurangnya kesadaran lingkungan pemangku kepentingan terhadap dampak jangka panjang senyawa minyak terhadap ekosistem laut dan pesisir. Salah satu contoh kegiatan bioremediasi dengan skala pilot adalah PT Maxus yang pernah melakukan land treatment $\mathrm{di}$ Pulau Pabelokan, tetapi hasilnya belum memuaskan. Natalia (2001) menyatakan efisiensi pengolahan hanya mencapai $8,3 \%$ dalam 5 bulan. Adapun penyebabnya diduga kurang baiknya studi pengolahan yang mencakup aspek mikrobiologis dan faktor faktor lingkungan.

\section{Perkembangan}

penelitian terkait bioremediasi di lingkungan laut mengalami peningkatan beberapa tahun belakangan ini. Penelitian dasar menyangkut inventarisasi dan isolasi bakteri pendegradasi minyak di perairan laut Indonesia sudah dimulai cukup lama di Teluk Jakarta (Thayib, 1978) dan beberapa penelitian lainnya yang berhasil mengisolasi bakteri hidrokarbonoklastik (Tabel 1).

Tabel 1. Bakteri hidrokarbonoklastik yang terisolasi dari perairan Indonesia

\begin{tabular}{|c|c|c|}
\hline Bakteri yang terisolasi & Lokasi & Sumber \\
\hline $\begin{array}{l}\text { Acinetobacter sp., Arthrobacter sp., } \\
\text { Micrococcus sp., Bacillus sp. }\end{array}$ & $\begin{array}{l}\text { Perairan Dumai, } \\
\text { Riau }\end{array}$ & Feliatra (1999) \\
\hline $\begin{array}{l}\text { Acinetobacter sp., Brevibacterium sp. } \\
\text { dan Bacillus sp. }\end{array}$ & $\begin{array}{l}\text { Pelabuhan Ujung } \\
\text { Pandang }\end{array}$ & $\begin{array}{l}\text { Thamrin dalam } \\
\text { Noor (1999) }\end{array}$ \\
\hline Pseudomonas cepacia, P. gladioli & $\begin{array}{l}\text { Perairan Selat } \\
\text { Makasar }\end{array}$ & Susilawati (2000) \\
\hline $\begin{array}{l}\text { Alcanivorax, Marinobacter, Bacillus, } \\
\text { Achromobacter, Alcaligenes, } \\
\text { Bacillus, Pseudomonas, Bordetella, } \\
\text { Sphingomonas, dan lain-lain }\end{array}$ & $\begin{array}{l}\text { Perairan Teluk } \\
\text { Jakarta dan } \\
\text { Kepulauan Seribu }\end{array}$ & $\begin{array}{l}\text { Darmayati et al. } \\
\text { (2008) }\end{array}$ \\
\hline $\begin{array}{l}\text { Aeromonas hydrophila, Enterobacter } \\
\text { agglomerans, Shewanella putrefaciens, } \\
\text { Acinetobacter haemolyticus and Vibrio } \\
\text { alginolyticus (Java Sea) }\end{array}$ & Perairan Laut Jawa & Darmayati (2009) \\
\hline $\begin{array}{l}\text { Bacillus sp., Acinetobacter sp.1 dan } \\
\text { Acinetobacter sp. } 2\end{array}$ & $\begin{array}{l}\text { Hutan mangrove, } \\
\text { Karawang }\end{array}$ & Masitho (1999) \\
\hline $\begin{array}{l}\text { Thalassospira profundamaris } \mathrm{Wp} 0211 \text {, } \\
\text { Rhodospirillaceae bacterium } \mathrm{PH} 3 \text { dan } \\
\text { Sphingomonas bacterium E4A9 }\end{array}$ & Perairan Cilacap & Lisdiyanti (2008) \\
\hline
\end{tabular}


Studi kemampuan bakteri untuk mendegradasi minyak mentah dan $\mathrm{PAH}$, digunakan sebagai salah satu cara penapisan dalam pencarian bakteri unggul sebagai agen bioremediasi. Bakteri yang digunakan merupakan hasil isolasi dari sedimen dan atau air dari beberapa lokasi, seperti Teluk Jakarta, Panajam, Melawai dan Cilacap (Darmayati et al., 2009a; Yopi et al., 2013; Hidayati et al., 2013; Andareas et al., 2013; Risdiyanto et al., 2013). Hasil penapisan dari isolat asal Teluk Jakarta menunjukkan bahwa Alcanivorax sp. TE-9 memiliki potensi yang paling tinggi, karena mampu memanfaatkan minyak mentah Arabian Light Crude Oil (ALCO), naftalena, dibenzothiofena, fluorena, fenantrena, pirena, fluorantena, fenotiazina dan campuran PAH. Jenis lainnya yaitu Bacillus sp. L41, isolat $R C O / B / 08 \_015$ dan isolat $R C O / B / 08 \_001$ mampu memanfaatkan minyak mentah ALCO, dibenzothiofena, fluorena, fenantrena, pirena, fluorantena, dan campuran $\mathrm{PAH}$ sebagai sumber energi dan karbonnya (Darmayati, 2009a). Murniasih et al. (2009) membuktikan bahwa isolat terpilih Pseudomonas sp Kalp3b22 dari Teluk Kumai dapat mendegradasi fenantrena sebesar 59,5\% selama 29 hari kultivasi.

Untuk meningkatkan efektivitas bioremediasi, pemilihan bakteri penghasil biosurfaktan juga dilakukan. Biosurfaktan adalah metabolit sekunder dari bakteri yang dapat digunakan untuk meningkatkan kemampuan mendispersi minyak menjadi butir-butir kecil, sehingga penguraiannya menjadi lebih cepat. Beberapa bakteri penghasil metabolit biosurfaktan telah berhasil diisolasi dari permukaan sedimen mangrove di Cilacap, yaitu Bacillus aquamaris, B. pumilus, Halobacillus trueperi dan Rhodobacteraceae bacterium. Untuk dapat memproduksi surfaktan dalam jumlah optimal, bakteri-bakteri tersebut membutuhkan sumber karbon yang berbeda antara satu jenis bakteri dengan bakteri lainnya (Hidayati et al., 2013).

Studi taksonomi dan gen fungsional dari bakteri pendegradasi minyak dengan menggunakan pendekatan molekuler menunjukkan hasil yang menarik. Sudiana (2009) menduga ada 11 genus novel dari Rhodobacteriales yang diisolasi dari perairan ini. Salah satu yang diusulkan adalah Salipiger pariensis sp. nov. Disamping itu, Teramoto et al. (2011) juga telah menemukan novel bakteri Oleibacter marinus gen. nov., sp.nov. dari air laut Teluk Jakarta. Beberapa isolat pendegradasi minyak yang diperoleh dari perairan tersebut mampu mendegradasi baik alkana maupun poliaromatik (Yopi, 2009). Disamping itu, ditemukan pula sekuen gen alkB delapan isolat terpilih yang menunjukkan prosentase keidentikan dengan alkana monooksigenase dari bank data berkisar $67-93 \%$ (Thontowi, 2008).

Pendekatan umum yang paling banyak dilakukan dalam upaya bioremediasi di lingkungan laut adalah biostimulasi, bioaugmentasi dan bioatenuasi (Atlas \& Philp, 2005). Penelitian dalam skala laboratorium telah dilakukan untuk mengetahui potensi pemanfaatan ketiga teknik tersebut untuk 
perairan Indonesia. Sebagai langkah awal dilakukan penelitian untuk mendapatkan agen bioremediasi ataupun formula nutrien yang tepat diterapkan di suatu wilayah tertentu. Dengan menggunakan sampel sedimen dari pantai berpasir terkontaminasi minyak mentah dan isolat Indonesia, kultur tunggal yang menunjukkan kemampuan dengan hasil laju degradasi terbaik tidak sama antara satu daerah dengan daerah lainnya. Strain Alcanivorax sp. TE-9 menunjukkan kinerja terbaik untuk sedimen tercemar minyak di Pulau Pari (Kepulauan Seribu), namun untuk sedimen Karang Song, Indramayu yang menunjukkan kemampuan terbaik adalah strain Bacillus sp. L41 (Nuchsin, 2011; Darmayati, 2011a). Jenis lain adalah Klebsiella sp. ICBD7866 yang efektif untuk bioremediasi tanah terkena tumpahan minyak di Tanjung Priuk (Santosa, komunikasi pribadi).

Hal yang berbeda terjadi pada pemilihan konsorsium bakteri. Konsorsium yang sama mampu menunjukkan kinerja terbaik tidak hanya di satu tempat namun bisa diterapkan di tempat lain. Namun demikian, tingkat kemampuannya berbeda antara di satu tempat dengan tempat lainnya. Kultur konsorsium A (campuran kultur Pseudomonas balearica st 101, Alcanivorax sp. TE-9 dan Bordetella sp, F-2) merupakan konsorsium terbaik yang mampu menurunkan konsentrasi cemaran minyak baik di Pulau Pari ataupun di Karang Song. Tingkat pengurangan cemaran minyak yang terjadi di P. Pari mencapai 70,5\% (Darmayati, 2011b), sedangkan untuk di Karang Song hanya $45,5 \%$. Hal ini diduga terkait dengan karakteristik minyak yang mencemari kondisi lingkungan, serta komunitas bakteri yang tersedia di lingkungan tersebut.

Pupuk sebagai sumber nutrien dalam bioremediasi memiliki sifat site spesific sehingga penggunaannya harus disesuaikan dengan lokasi penelitian. Penelitian dengan menggunakan empat jenis pupuk lepas lambat impor menunjukkan bahwa pupuk yang terbaik untuk meningkatkan degradasi minyak di Pulau Pari adalah "Osmocote" (Kunarso \& Darmayati, 2011), sedangkan untuk di Karang Song (Indramayu) adalah pupuk "Terra" (Pusat Penelitian Oseanografi, 2010). Seleksi pupuk lepas lambat untuk meningkatkan laju degradasi minyak di perairan Cilacap, menunjukkan bahwa pupuk pertanian produk lokal (Gramafix) terbukti mampu mengungguli efektivitas "Osmocote" (Darmayati et al., 2013). Dengan demikian, penggunaan pupuk lokal cukup potensial untuk dapat menggantikan pupuk impor.

Pendekatan lain adalah penggunaan bioaktivator. Adapun komponen utama bioaktivator terdiri atas sumber $\mathrm{N} \& \mathrm{P}$, surfaktan, kosurfaktan, dan bahan-bahan organik dari lemak atau minyak yang tidak atau kurang larut dalam air. Air laut yang digunakan diambil dari perairan pantai Ujung Pandang, sedangkan minyak bumi yang dijadikan contoh adalah minyak mentah Arjuna. Hasilnya menunjukkan bahwa penambahan $15 \%$ bioaktivator dapat meningkatkan 
kemampuan degradasi sampai 49,2\% dalam jangka waktu 336 jam (14 hari) (Ilyas dalam Noor, 1999).

Kementerian Kelautan dan Perikanan pernah melakukan uji coba laboratorium dengan menggunakan bakteri Mikro Morr-E-3360. Hasil penelitian menunjukkan bahwa bakteri ini belum sepenuhnya efektif untuk menguraikan senyawa PAH. Endapan yang mengapung (bahan residu bioremediasi), masih mengandung senyawa PAH yang sangat tinggi $(14,68 \%)$ dan penurunan nilai oksigen terlarut juga cukup signifikan (Anonim, 2011).

Sebagai tahap lanjutan, penelitian di lapangan sudah mulai dilakukan dengan menggunakan pendekatan mesokosm. Percobaan dengan menggunakan kolom pasir yang ditempatkan di daerah intertidal Pulau Pari, menunjukkan bahwa pupuk lepas lambat "Osmocote" mampu meningkatkan laju degradasi minyak mentah Arabian Light Crude Oil (Darmayati, 2010). Di Karang Song Indramayu, eksperimen in-situ dengan pendekatan mesokosm pada sedimen tercemar minyak mentah $10000 \mathrm{mg} /$ $\mathrm{kg}$ menunjukkan bahwa bioaugmentasi dengan menggunakan konsorsium bakteri A lebih efektif daripada biostimulasi dengan pupuk lepas lambat 'Osmocote'. Namun demikian, biostimulasi masih lebih baik daripada bioaugmentasi dengan kultur tunggal Alcanivorax sp. TE-9 (Ruyitno et al., 2011). Jika ditinjau dari efektivitasnya dalam menurunkan konsentrasi alkana, degradasi minyak yang tertinggi $(98 \%, 30$ hari setelah perlakuan) teramati pada perlakuan penambahan kultur tunggal Alcanivorax sp. TE-9 (Munawir et al., 2012). Hal yang berbeda terjadi di Cilacap, urutan efektivitas teknik bioremediasi nya adalah sebagai berikut: biostimulasi plus konsorsium $>$ biostimulasi dan kultur tunggal $>$ kultur tunggal $>$ konsorsium > biostimulasi (Darmayati et al., 2014a; Darmayati et al., 2014b).

Cara lain yang digunakan dalam uji coba skala pilot adalah menggunakan petak-petak percobaan berukuran $0,5 \times 0,5 \mathrm{~m}$ di pantai Surabaya Timur. Hasilnya menunjukkan bahwa perlakuan penambahan nutrien organik"petroganik" menunjukkan hasil yang positif dalam proses bioremediasi tanah tercemar minyak mentah asal Cepu $\left(1 \mathrm{~L} / 0,25 \mathrm{~m}^{2}\right)$. Perlakuan pembalikan tanah mampu meningkatkan laju degradasi dalam eksperimen ini (Munawar et al., 2007). Penambahan pupuk anorganik (NPK) juga mampu meningkatkan degradasi minyak dengan tingkat yang lebih rendah (Munawar \& Mukhtasor, 2007).

Hasil dari berbagai studi di atas dapat terlihat potensi pemanfaatan teknologi bioremediasi untuk mengurangi dampak cemaran minyak di perairan laut dan pesisir Indonesia. Meskipun untuk dapat segera diaplikasikan, masih perlu pengembangan dengan banyak penyempurnaan baik dari segi pemahaman proses, teknik maupun agen bioremediasinya. Kunci keberhasilan teknik ini adalah kemampuan menciptakan lingkungan terbaik agar 
bakteri (agen bioremediasi lainnya) dapat bermetabolisme secara optimal. Hal ini menyebabkan teknik yang diterapkan menjadi spesifik untuk setiap kawasan. Dukungan komitmen dan kemitraan yang kuat antar berbagai pihak terkait sangat dibutuhkan agar teknologi ini dapat berkembang dan diterapkan untuk menanggulangi pencemaran di perairan laut dan pesisir Indonesia.

\section{PENUTUP}

Teknik bioremediasi (secara biologis) dalam penanggulangan minyak di Indonesia untuk kawasan pesisir dan laut belum banyak digunakan. Potensi keberhasilan dalam pemanfaatannya cukup tinggi, akan tetapi terkendala oleh keterbatasan data. Oleh karena itu, pengkajian yang mendalam masih perlu dilakukan. Saat ini perkembangan teknik terus dilakukan, tidak hanya di negaranegara yang sudah maju namun juga di Indonesia yang banyak mengalami tumpahan minyak. Berbagai studi yang dilakukan di Perairan Indonesia semakin menunjukkan bahwa teknik bioremediasi cukup menjanjikan untuk dikembangkan.

\section{DAFTAR PUSTAKA}

Aditiawati P., D. Indriani and N. P. Aryantha., 2001. Production of biosurfactan by hydrocarbonoclastic bacteria for oil spills bioremediation. Report on Competitive Grant. Microbiology Laboratory Biology Department, ITB, Bandung.
Andareas, P., H. Pramono dan A. Irianto. 2013. Biodegradasi minyak solar menggunakan isolat bakteri indigenous mangrove Tritih Kulon, Cilacap. Makalah dipresentasikan dalam Seminar Nasional Bioremediasi ke-3. IPB International Convention Center, Bogor, 23-24 Oktober 2013.

Anonim, 2011. Progress Pengujian bioremediasi untuk penanggulangan tumpahan minyak. Badan Riset Kelautan dan Perikanan, Departemen Kelautan. 7 p.

Atlas R. M. and J. Philp. 2005. Bioremediation: applied microbial solutions for realworld environmental cleanup. ASM Press, Washington, D.C., pp. 1-292.

Atlas, R. M. 1981. Microbial degradation of petroleum hydrocarbons: an environmental prespective. Microbiol. Rev., 45, 180-209.

Atlas, R. M. 1995. Petroleum biodegradation and oil spill bioremediation. Mar. Pollut. Bull., 31, 178-182.

Atlas, R. M. and T. C. Hazen. 2011. Oil Biodegradation and Bioremediation: A Tale of the Two Worst Spills in U.S. History. Environmental Science \& Technology, 45 (16), 67096715 
Bocard, C. O., P. Renault and J. Croquette. 1979. Cleaning products used in operations after the Amoco Cadiz disaster. In: Proceding of the International Oil Spill Conference, American Petroleum Institute. Washington, D.C. p.425.

Bragg, J. R., R. C. Prince, E. J. Harner and R. M. Atlas. 1994. Effectiveness of bioremediation for the Exxon -Valdez oil-spill. Nature 368: 413-418.

Darmayati, Y. 2009a. Seleksi dan karakterisasi bakteri laut pendegradasi minyak dari Teluk Jakarta. Prosiding Seminar Nasional Perikanan 2009, 03 - 04 Desember 2009, Jakarta, $497-507$.

Darmayati, Y. 2009b. Bioremediation of crude oil contaminated sediment using slow release fertilizer: hydrocarbonoclastic bacterial population dynamics. Ilmu Kelautan. Februari 2010. Vol 1. Edisi Khusus : 1 - 14

Darmayati, Y. 2010. Bioremediation of crude oil contaminated sediment using slow fertilizer : Hydrocarbonoclastic bacteria population dynamics. Indonesia Jurnal Ilmu Kelautan 2: $462-$ 476

Darmayati, Y. 2011a. Marine oil degrading bacteria selection for remediating oil polluted sandy beach in pari island complex, Seribu island. Paper presented in Pertemuan Ilmiah Tahunan dan Kongres ISOI, 25-27 September 2011, Makassar

Darmayati, Y. 2011b. Selection of bacterial consortium for enhancing bioremediation process in oil spilled sandy beach of Seribu Island. Paper dipresentasikan di "Internasional Symposium on coastal resources Management and development Diponegoro University, Semarang, $29-30$ November 2011.

Darmayati, Y. 2013. Pengenalan tentang bioremediasi untuk perairan pantai tercemar minyak. Oseana. 38 (2): 68-78.

Darmayati, Y., H. S. Sanusi, T. Prartono, D. A. Santosa and Ruyitno. 2014b. The efficacy of bacterial single strain and consortium application for oil bioremediation in Cilacap sandy beach by using mesocosm approach. Paper dipresentasikan dalam Seminar Nasional Bioremediasi ke-3. IPB International Convention Center, Bogor, 23-24 Oktober 2013.

Darmayati, Y., H. S. Sanusi, T. Prartono, D. A. Santosa and Ruyitno. 2014a. The efficacy of bioaugmentation for oil bioremediation in tropical sandy beach using 
mesocosm approach. Paper dipresentasikan dalam IOC/ WESTPAC $9^{\text {th }}$ International Scientific Symposium, 2225 April 2014, Nha Trang, Vietnam.

Darmayati, Y., S. Harayama, S. Yamazoe, A. Hatmanti, Sulistiani, Ruyitno and D. H. Kunarso 2008. Hydrocarbonoclastic bacteria from Jakarta Bay and Seribu Islands. Mar. Res. Indonesia 33 (1): 55-64.

Feliatra. 1999. Isolation, Identification and biodegradation of petroleum by bacteria in the Malacca Strait. In: Proceedings of the First Indonesian Seminar on Marine Biotechnology '98 (Eds.: Soemodihardjo, S., R. R. Satari and S. Saono) (Indonesian). Indonesian Institute of Sciences, Jakarta. 291-304.

Gunanto, E. S. and Y. Seo. 2010. Timor Sea disaster. Tempo, 30 (XI): 24-30.

Hidayati, N. V., Y. Darmayati, C. N. Sari and A. D. Syakti. 2013. Screening of biosurfactant producing bacteria isolated from hydrocarbons contaminated sediment in Cilacap coast. Makalah dipresentasikan dalam Seminar Nasional Bioremediasi ke-3. IPB International Convention Center, Bogor, 2324 Oktober 2013.
Hose J. E., M. D. McGurk, G. D. Marty, D. E. Hinton, E. D. Brown and Baker T. T. 1996. Sublethal effects of the Exxon Valdez oil spill on herring embryos and larvae: morphological, cytogenetic, and histopathological assessments, 1989-1991. Canadian Journal of Fisheries and Aquatic Science, 53: 2355-2365.

Hozumi T., H. Tsutsumi and M. Kono. 2000a. Bioremediation on the shore after an oil soil from the Nakhodka in the Sea of Japan. I. chemistry and characteristics of heavy oil loaded on the Nakhodka and biodegradation tests by a bioremediation agent with microbiological cultures in the laboratory. Marine Pollution Bulletin 40 : 308-314

Kunarso, D. H. dan Y. Darmayati. 2011. In vitro biostimulation study in Indramayu sandy beach sediment. Paper dipresentasikan di "Internasional Symposium on Coastal Resources "Management and Development". Diponegoro University, Semarang, 29 - 30 November 2011

Lisdiyanti P. 2008. Analisa komunitas bakteri laut: dalam aplikasi teknologi bioremediasi cemaran minyak mentah. Laporan Akhir 2008. Program Kompetitif LIPI, DIPA Biro Perencanaan dan Keuangan LIPI dan Pusat 
Penelitian Oseanografi LIPI. Jakarta

Masitho, D. 1999. Biodegradasi minyak bumi oleh bakteri dari ekosistem mangrove. [Tesis]. Program Studi Pengelolaan Alam dan Lingkungan. Program Pasca Sarjana, IPB. 47 p.

Maulidiyah. 2012. Estimasi biaya kerugian akibat tumpahan minyak di Perairan Cilacap. [Thesis]. Program Studi Teknik Manajemen Pantai, Sepuluh Nopember Institute of Technology. Program Pasca Sarjana, Institut Teknologi Sepuluh Nopember.104 pp.

Miller, J. 1984. The West Falmouth Oil Spill, Hydrocarbons in The Salth Marsh Ecosystem. The National Academic Press, New York.

Munawar, Mukhtasor dan T. Surtiningsih. 2007. Bioremediasi tumpahan minyak mentah dengan metode biostimulasi nutrient organik di lingkungan pantai Surabaya Timur. Berk. Penel. Hayati. 13: 91-96.

Munawir, K., Y. Darmayati dan M. D. Yeni. 2012. Efektivitas proses bioremediasi in situ tumpahan minyak di Pantai Karang Song Indramayu terhadap senyawa alkana. Oseanologi dan Limnologi di Indonesia 38 (1): 81-93.
Murniasih, T., Yopi dan Budiawan, 2009. Biodegradasi fenantren oleh bakteri laut Pseudomonas sp KaIP3b22 asal Kumai Kalimantan Selatan. Makara Sains, 13 (1): 77-80.

Natalia J. 2001. Evaluasi bioremediasi tanah tercemar petroleum hydrocarbons dengan land treatment. [Skripsi]. Fakultas Teknik Sipil dan Perencanaan, Institut Teknologi Bandung.

National Research Council (US), 2003. Committee on Oil in the Sea: Inputs, Fates, and Effects. Washington (DC): National Academies Press (US); http:// www.ncbi.nlm.nih.gov/books/ NBK220687/\#ddd00064

Noor, A. 1999. Pengembangan bioaktivator UH-1 untuk mengatasi pencemaran minyak bumui di laut. Dalam: Soemodihardjo, S., R.M. Sataridan S. Saono (eds.). Prosiding Seminar Bioteknologi Kelautan I '98. Jakarta, 14 - 15 Oktober 1998. Lembaga Ilmu Pengetahuan Indonesia, Jakarta. 339 - 342.

Nuchsin, R. 2011. Laporan Akhir: Kajian Bioremediasi di Perairan Pantai Cilacap. Pusat Penelitian Oseanografi, LIPI, $50 \mathrm{pp}$.

OTA. 1990. Coping With An Oiled Sea: An Analysis of Oil Spill 
Response Technologies, OTABP-O-63, Washington, DC.

Prince R. and R. M. Atlas. 2005. Bioremediation of marine oil spills. In Atlas RM, Philp $\mathrm{J}$, editors. Bioremediation: applied microbial solutions for real-world environmental cleanup. ASM Press. Washington DC, USA. 269292.

Pusat Penelitian Oseanografi. 2010. Laporan Akhir Uji Coba Teknik Bioremediasi di Pantai Berpasir Tercemar Minyak di Balongan. Pusat Penelitian Oseanografi - Lembaga Ilmu Pengetahuan Indonesia, Jakarta. 21 pp.

Risdiyanto, A. Irianto dan M. H. Sastranegara. 2013. Biodegradasi petroleum menggunakan bakteri indigenous dari Perairan Muara Sungai Donan Cilacap. Makalah dipresentasikan dalam Seminar Nasional Bioremediasi ke-3. IPB International Convention Center, Bogor, 23-24 Oktober 2013.

Rusdi S. 2008. Discussion on marine pollution handling in Indonesia. [periodical]. http:// www.indonesiamaritimeclub. com $/ 2008 / 01 / 05 /$ menyoalpenanganan-pencemaran-lautdi-indonesia/.html $[23$ Februari 2008]
Ruyitno, L. I. Sutiknowati, A. Hatmanti and Y. Darmayati. 2011. In situ experiment: comparison of bioaugmentation and biostimulation effect on oil biodegradation in Pari Island oil contaminated sandy beach, Seribu Island. Paper dipresentasikan di Internasional Symposium on coastal resources "Management and development" Diponegoro University, Semarang, 29 - 30 November 2011

Spies, R. B., J. J. Stegeman, D. E. Hinton, B. Woodin, R. Smolowitz, M. Okihiro and D. Shea. 1996. Biomarkers of hydrocarbon exposure and sublethal effects in embiotocid fishes from a natural petroleum seep in the Santa Barbara Channel. Aquat. Toxicol. 34: 195-219.

Sudiana, M. 2009. Microbial diversity of crude oil degrading bacteria in sea water and column reactors, Presentation on Final Meeting of LIPI-NITE Cooperation Project, Jakarta, $10^{\text {th }}$ February 2009.

Sudrajad, A. 2006. Tumpahan minyak di laut dan beberapa catatan kasusnya di Indonesia. Inovasi 6(18) [periodical]. http://io.ppijepang.org/article.php?id.html [27 February 2008]

Sugoro I., and P. Aditiawati, 2003. Analysis of oil sludge biodegradation by 
hydrocarbonoclastic bacteria using land farming technique in laboratory scale. p. 530-536, In D. Natalia (ed.), Proceedings of the Annual Scientific Meeting Indonesian Society for Microbiology 2003, Indonesian Society for Microbiology, Jakarta (In Indonesian).

Swannell, O., P. J. Richard, K. Lee and M. McDonagh. 1996. Field evaluations of marine oil spill bioremediation. Microbiological Reviews. 60: 342-365.

Teramoto, M., M. Ohuchi, A .Hatmanti, Y. Darmayati, Y. Widyastuti, S. Harayama and S. Fukunaga. 2011. Oleibacter marinus ge.nov., sp.nov., a bacterium that degrades petroleum aliphatic hydrocarbons in a tropical marine environment. International Journal of Systematic and Evolutionary. 61(Pt 2): 375-80

Thayib, S. T., 1978. Catatan tentang mikroorganisme hidrokarbonklastik dari perairan pantai dan laut Teluk Jakarta. Oseanologi di Indonesia. 10:1-7.

Thontowi, A. 2008. Potensi bakteri pendegradasi hidrokarbon alkana sebagai agen bioremediasi pencemaran minyak di laut Indonesia. [Tesis]. Program Studi
Bioteknologi, Sekolah pasca Sarjana, IPB. 49 p

Tsutsumi, H., M. Kono, K. Takai and T. Manabe. 2000. Bioremediation on the shore after an oil spill from the Nakhodka in the sea of Japan. III. Field test of bioremediation agent with microbiological cultured for the tratment of an oil spill. Mar. Poll. Bull. 40: 320-324.

White, I. C. and J. M. Baker. 1998. The Sea Empress oil spill in context. (Paper presented at the international conference on the Sea Empress Oil Spill 11th - 13th February 1998, Cardiff, Wales). The international Tanker Owners Pollution Federation Ltd. pp: 33.

Yopi, N. Rahmani, A. C. Djohan, A. Purnama, and A. Thontowi. 2013. Isolation of hydrocarbonoclastic bacteria for polyaromatic hydrocarbon degradation. Makalah dipresentasikan dalam Seminar Nasional Bioremediasi ke-3. IPB International Convention Center, Bogor, 23-24 Oktober 2013.

Yopi. 2009. Molecular screening of hydrocarbon monoand di-oxygenase genes from Indonesian isolates. Presentation on Final Meeting of LIPI-NITE Cooperation Project, Jakarta, $10^{\text {th }}$ February 2009. 
Yoswaty, D. 2002. Pemanfaatan Bakteri Pemecah Minyak Dalam Proses Bioremediasi. [Tesis]. Jakarta. Universitas Indonesia.
Zhu, X., A. D. Venosa, M. T. Suidan, and K. Lee, 2001. Guidelines for the Bioremediation of Marine Shorelines and Freshwater Wetlands. U.S. Environmental Protection Agency, Cincinnati, OH 45268. Pp.156. 